\title{
Rancang Bangun Sistem Pemantauan Luaran Pico Generator pada Pembangkit Listrik Tenaga Bayu Sumbu Vertikal Menggunakan Arduino UNO
}

\author{
Fauzun Atabiq ${ }^{1 *}$, Muhamad Agil Wildan ${ }^{1}$, dan Muhammad Ridlo Alfianto ${ }^{1}$ \\ ${ }^{1}$ Politeknik Negeri Batam, Batam, Indonesia \\ *Email: atabiq@polibatam.ac.id
}

\begin{abstract}
Abstrak - Kebutuhan akan penggunaan energi listrik di dunia pada umumnya, di Indonesia pada khususnya terus meningkat seiring berjalannya waktu. Perbandingan antara jumlah penduduk yang sudah menikmati energi listrik dengan jumlah total penduduk yang ada di Indonesia disebut dengan rasio elektrifikasi. Salah satu upaya untuk memenuhi kebutuhan energi adalah menggunakan pembangkit listrik terbarukan yaitu pembangkit listrik tenaga bayu. Saat ini, Politeknik Negeri Batam memiliki turbin angin sumbu vertikal tipe savonius 3 blades yang berada di belakang gedung W7. Penelitian ini bertujuan untuk membuat sistem monitoring luaran pico generator menggunakan mikrokontroler arduino UNO secara real time dan membuat aplikasi berbasis komputer untuk menampilkan data hasil monitoring. Penelitian dilakukan dengan melakukan pengujian setiap komponen monitoring dan menggabungkan seluruh komponen tersebut menjadi sebuah sistem monitoring. Desain turbin pada penelitian mengalami perubahan, turbin angin yang digunakan yaitu turbin angin savonius dengan 6 blades. Hasil penelitian berupa data hasil monitoring dan aplikasi berbasis komputer untuk menampilkan data hasil monitoring. Monitoring dilakukan pada tanggal 11-17 Desember 2020. Rata-rata kecepatan angin yang ada di lingkungan Politeknik Negeri Batam yaitu $3.8 \mathrm{~m} / \mathrm{s}$. PLTB bekerja efektif untuk menghasilkan tegangan listrik selama 14.6 jam dalam satu minggu. Potensi daya angin maksimum yang dapat di ekstraksi oleh turbin angin sebesar 80.68 watt. Tegangan maksimum yang dapat dihasilkan oleh generator sebesar 1.1V. Tegangan luaran berbanding lurus dengan putaran generator, semakin besar putaran generator semakin besar tegangan yang dihasilkan.
\end{abstract}

Kata Kunci: Generator, Pembangkit Listrik Tenaga Bayu, Monitoring

\section{Pendahuluan}

KEBUTUHAN akan penggunaan energi listrik di dunia pada umumnya, di Indonesia pada khususnya terus meningkat seiring berjalannya waktu [1]. Perbandingan antara jumlah penduduk yang sudah menikmati energi listrik dengan jumlah total penduduk yang ada di Indonesia disebut dengan rasio elektrifikasi [2]. Tingkat rasio elektrifikasi terbesar berada di wilayah kota-kota besar atau pulau Jawa dengan nilai diatas 90\%. Upaya untuk meningkatkan rasio elektrifikasi di
Indonesia terutama pada wilayah perdesaan, daerah terpencil, dan pulau terluar adalah dengan membuat pembangkit listrik terbarukan sebagai energi alternatif yang ramah lingkungan, salah satunya adalah pembangkit listrik tenaga bayu (PLTB)[3].

Pembangkit listrik tenaga bayu memanfaatkan energi angin yang ditangkap oleh turbin angin yang menimbulkan energi mekanik. Kemudian energi mekanik tersebut di konversi menjadi energi listrik yang berasal dari generator [4]. Terdapat dua jenis turbin angin berdasarkan perputaran sumbu yaitu turbin angin sumbu vertikal dan turbin angin sumbu horizontal [5]. Permasalahan yang timbul dalam pemanfaatan energi angin sebagai pembangkit adalah kecepatan angin yang ada di Indonesia tergolong rendah. Kecepatan angin yang rendah dapat menyebabkan turbin tidak berputar mengakibatkan listrik yang dihasilkan fluktuatif, sehingga energi angin yang tersedia cocok untuk pembangkit listrik dalam skala kecil [3].

Pada tahun 2015, penelitian yang dilakukan oleh Wahyudi dkk, perancangan mini generator untuk menghasilkan daya keluaran 200W pada karakteristik angin kecepatan rendah. Hasil yang didapatkan adalah pada kecepatan $495 \mathrm{rpm}$ nilai tegangan saluran yang dihasilkan sebesar $48,86 \mathrm{~V}$, arus saluran 2,09 A, daya 154,47 $\mathrm{W}$, dan efisiensi sebesar 85,97\%. Generator bekerja dengan baik pada karakteristik angin yang rendah [6].

Pada tahun 2016, penelitian yang dilakukan oleh Bambang Suryadi yaitu menguji performa generator jenis kutub banyak menggunakan turbin angin sumbu vertikal tipe savonius. Hasil pengujian menunjukkan generator dapat bekerja pada kecepatan angin 3,2 m/s hingga 5,1 m/s. Pada kecepatan angin tersebut generator berputar mencapai $108 \mathrm{rpm}$ dengan tegangan luaran sebesar 1,7V dan arus luaran sebesar 0,9 A [7].

Saat ini Politeknik Negeri Batam memiliki turbin angin sumbu vertikal tipe savonius 3 blades yang berada di belakang gedung W7 [3]. Permasalahan yang terjadi adalah pada PLTB tersebut belum terdapat sistem monitoring luaran yang dihasilkan pico generator secara real time, sehingga diperlukan keberlanjutan dari proyek pengembangan pembangkit listrik tenaga bayu yang ada di Politeknik Negeri Batam. 


\section{Metodologi}

\section{A. Perancangan Penelitian}

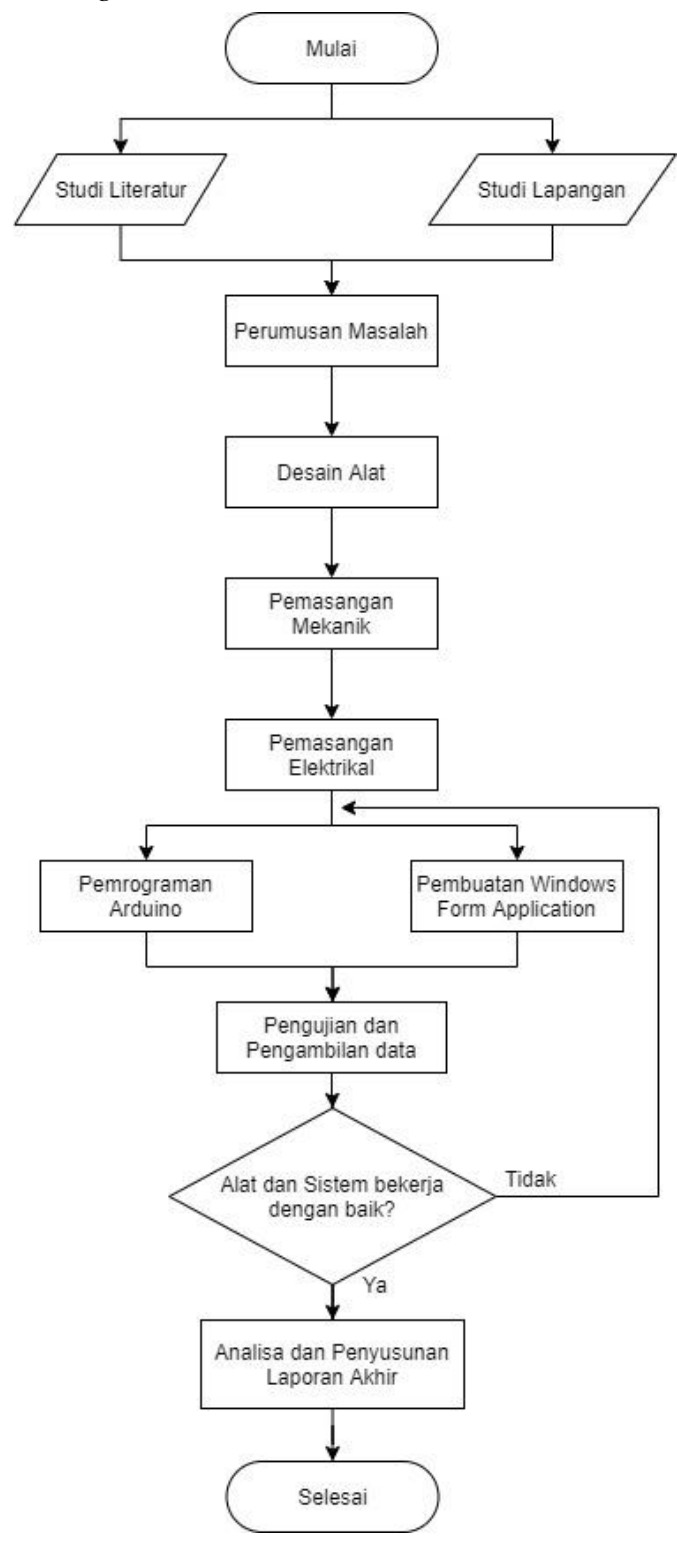

Gambar 1. Diagram Alir Penelitian

Terdapat langkah-langkah untuk menjawab permasalahan yang telah dirumuskan, sebagai berikut:

1. Studi Literatur

Studi literatur pada penelitian ini yaitu mempelajari berbagai ilmu yang berkaitan dengan pembangkit listrik tenaga bayu sumbu vertikal dan sistem monitoring yang diperoleh dari berbagai sumber seperti jurnal, skripsi, buku, publikasi ilmiah, dan harga dari alat dan bahan yang digunakan.

2. Studi Lapangan

Studi lapangan dilakukan secara langsung yang meliputi pengukuran turbin angin yang sudah terpasang di belakang workshop W7 Politeknik Negeri Batam untuk melakukan desain alat dan penempatan panel serta sensor untuk mendukung sistem monitoring.
3. Perumusan Masalah

Perumusan permasalahan pada penelitian ini yaitu bagaimana membuat sebuah sistem untuk melakukan monitoring luaran dari pico generator secara real-time menggunakan arduino sebagai pengolahan data dan windows form application sebagai penampil data pada personal computer.

4. Desain Alat

Desain alat pada penelitian ini terbagi menjadi dua, yaitu desain pembangkit listrik secara umum dan desain kotak panel listrik.

5. Pemasangan Mekanik

Turbin angin sumbu vertikal beserta pico generator sudah terpasang di belakang workshop W7 Politeknik Negeri Batam. Pemasangan mekanik yang dilakukan yaitu pemasangan panel yang berisi perangkat keras dari sistem Monitoring, pemasangan sensor untuk mendapatkan informasi data berupa luaran pico generator, dan pemasangan pipa sebagai jalur kabel.

6. Pemasangan Elektrikal

Pemasangan elektrikal meliputi pemasangan wiring komponen komponen yang digunakan di dalam panel dan pemasangan sensor untuk mendukung sistem Monitoring.

7. Pemrograman Arduino

Pemrograman arduino dilakukan untuk mengolah data yang diterima oleh sensor agar dapat ditampilkan pada LCD dan disimpan pada micro SD Card.

8. Pemrograman Windows Form Application

Pemrograman windows form application dilakukan dengan menggunakan software Visual Studio untuk mengubah file text (.txt) yang berasal dari micro $S D$ card menjadi bentuk tabel.

9. Pengujian dan Pengambilan Data

Pengujian sistem dilakukan dengan cara mengambil data pembacaan luaran pico generator dari sensor dan program bekerja sesuai dengan fungsi sistem Monitoring.

10. Analisa dan Penyusunan Laporan Akhir

Data yang telah didapat akan dilakukan analisa perbandingan antara luaran pico generator terhadap putaran turbin.

\section{B. Perancangan sistem kerja}

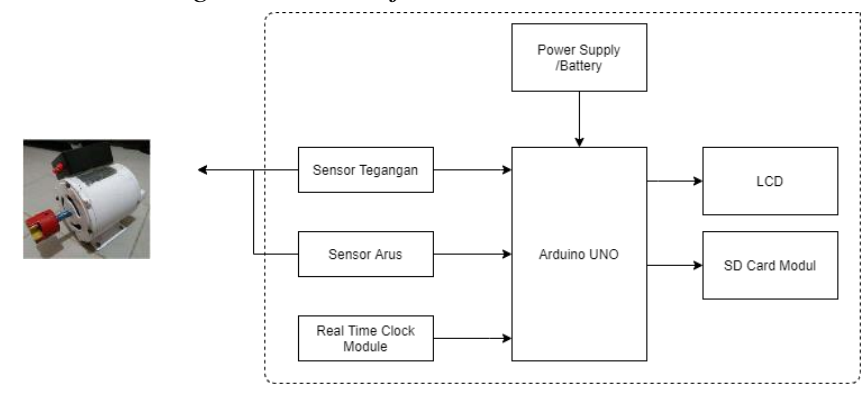

Gambar 2. Blok Diagram Sistem

Dari blok diagram di atas, angin yang berhembus akan menggerakkan turbin angin dan menghasilkan energi mekanis. Sudut dari turbin angin sumbu vertikal terhubung langsung dengan pico generator dimana posisi dari pico generator berada tepat di titik tengan dari turbnin angin. Luaran dari pico generator kemudian dibaca oleh sensor arus dan tegangan. Data 
yang diperoleh dari sensor tersebut kemudian di olah pada arduino dan ditampilkan pada LCD. Data juga akan tersimpan pada micro sd card dalam bentuk file text (.txt). Untuk menampilkan data berupa tabel, file text (.txt) pada micro $S D$ card di konversi pada personal Computer menggunakan windows form application yang telah dibuat. Pada sistem terdapat real time clock modul untuk memberikan masukan pada arduino berupa tanggal dan waktu secara real Time.

\section{Perancangan Mekanik}
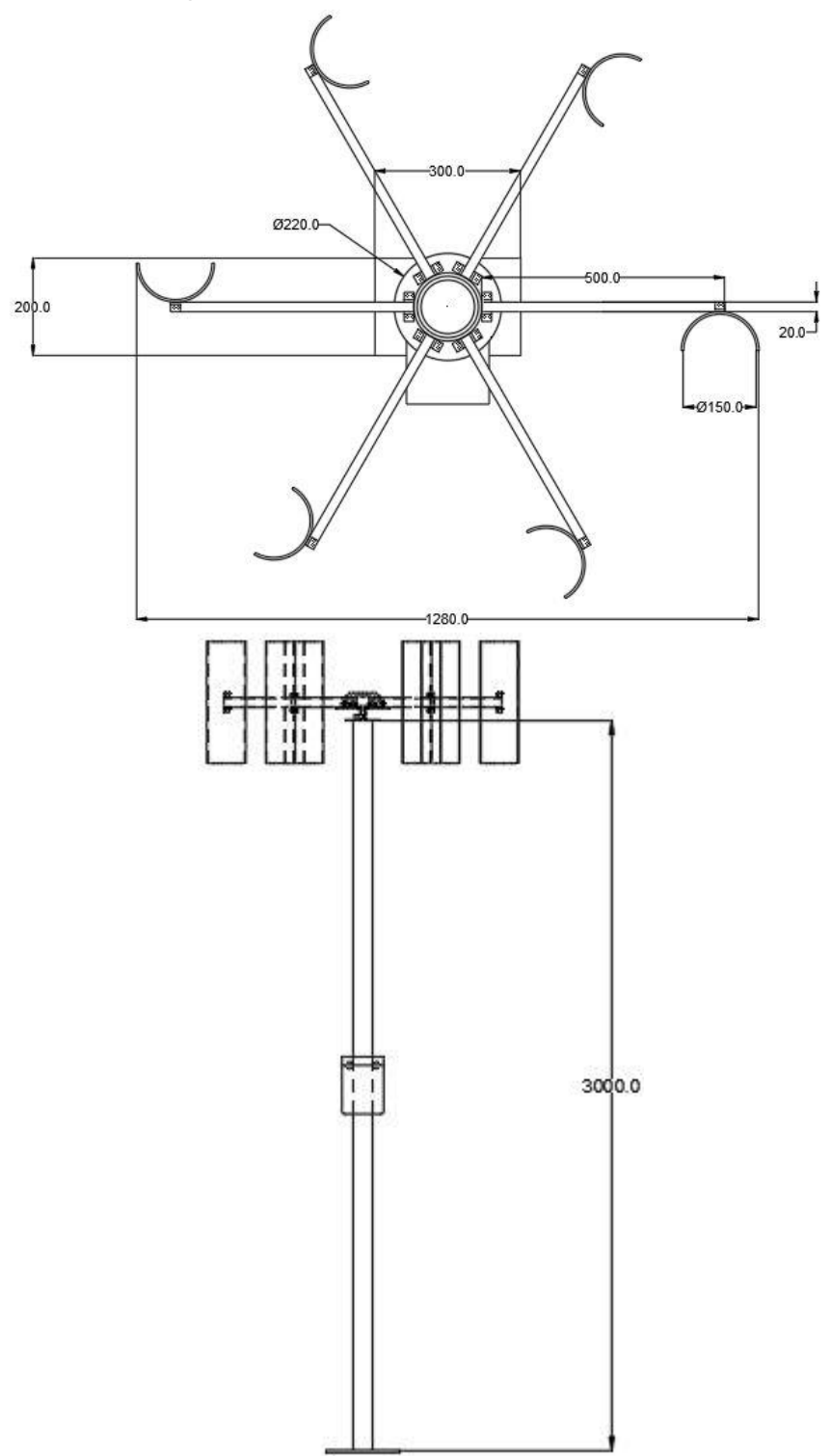

Gambar 3. Perancangan Mekanik Turbin Angin Savonius 6 Sudu

Turbin angin memiliki diameter total sebesar $1.28 \mathrm{~m}$. Turbin angin memiliki 6 sudu dimana setiap sudu berukuran panjang $50 \mathrm{~cm}$ dan diameter $15 \mathrm{~cm}$. Untuk menghubungkan sudu dengan generator digunakan lengan turbin yang berasal dari besi hollow dengan ukuran panjang $50 \mathrm{~cm}$, lebar $2 \mathrm{~cm}$ dan tinggi $4 \mathrm{~cm}$. Terdapat plat besi berbentuk lingkaran dengan diameter $22 \mathrm{~cm}$ yang digunakan sebagai dudukan untuk menghubungkan generator dengan lengan turbin. Tiang PLTB memiliki tinggi sebesar 3 meter.

\section{Perancangan elektrikal}

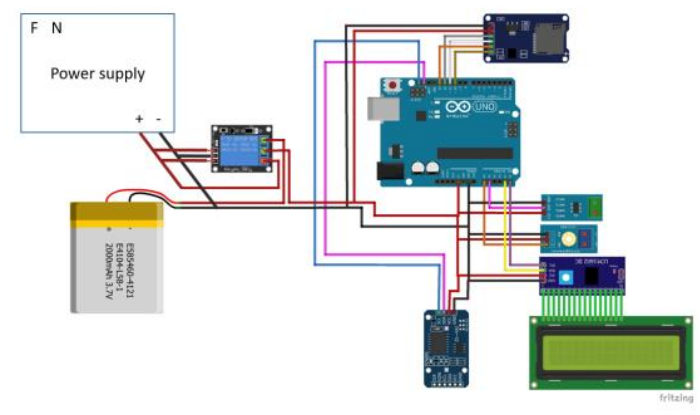

Gambar 4. Perancangan pengawatan sistem monitoring

Perancangan elektrikal terdiri dari arduino, sensor tegangan, sensor arus, I2C dan LCD, baterai, modul micro SD card, dan modul real time clock. Baterai berfungsi sebagai supply tegangan. Arduino berfungsi sebagai pengolahan data. Sensor tegangan terhubung pada pin $5 \mathrm{v}$ dan GND sebagai sumber tegangan dan terhubung pada pin A0 sebagai masukan data. Sensor arus terhubung pada pin $5 \mathrm{v}$ dan GND sebagai sumber tegangan dan terhubung pada pin A1 sebagai masukan data. I2C terhubung pada pin $5 \mathrm{v}$ dan GND sebagai sumber tegangan, SDA terhubung pada pin A4 dan SCL terhubung pada pin A5. Modul real time clock terhubung pada pin 5v dan GND sebagai sumber tegangan, pin SDA terhubung pada pin SDA yang tersedia pada arduino, dan SCL terhubung pada pin SCL yang tersedia pada arduino. Modul micro $S D$ card terhubung pada pin 5v dan GND sebagai sumber tegangan, pin SCK terhubung pada pin 13, pin MISO terhubung pada pin 12, pin MOSI terhubung pada pin 11, dan pin CS pada pin 10.

\section{E. Perancangan diagram alir pemrograman mikrokontroler}

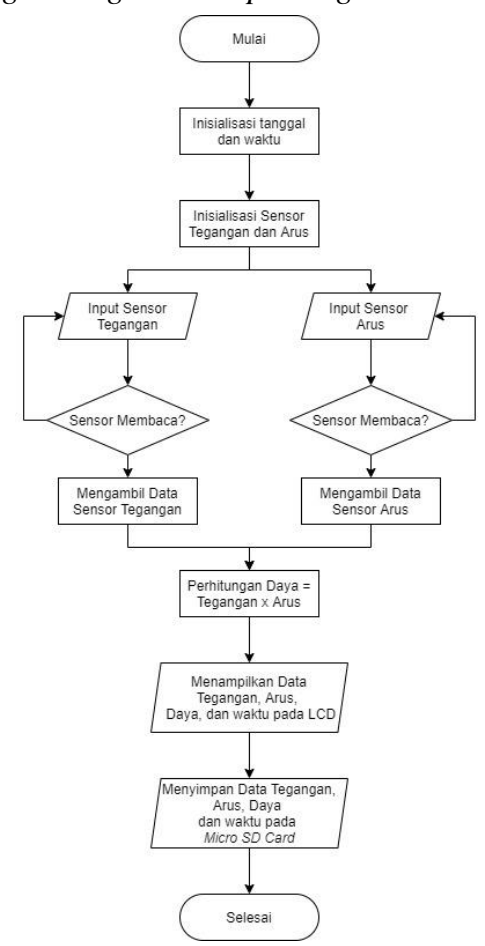

Gambar 5. Diagram alir pemrograman mikrokontroler

Sistem monitoring luaran pico generator menggunakan mikrokontroler arduino UNO. Pada pemrograman arduino 
diawali dengan inisialisasi sensor tegangan, sensor arus, dan waktu. Kemudian sensor tegangan dan sensor arus membaca nilai luaran dari pico generator, jika kedua sensor membaca maka akan dilakukan pengambilan data. Data berupa tegangan, arus, dan waktu akan ditampilkan pada LCD serta data tersebut disimpan pada micro SD Card

\section{HASIL \& PEMBAHASAN}

A. Hasil monitoring PLTB 11 Desember 2020

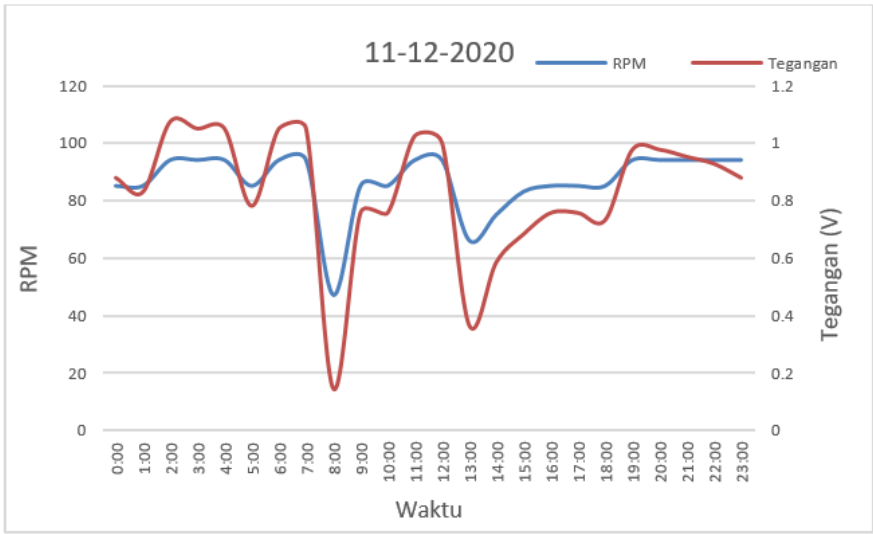

Gambar 6. Hasil Monitoring PLTB 11 Desember 2020

Pada saat tanggal 11 Desember 2020, nilai tegangan luaran minimum yang termonitor adalah sekitar 0.147 Volt dan nilai tegangan luaran maksimum yang dihasilkan hanya menunjukkan sekitar 1.1 Volt. Nilai putaran generator minimum sebesar $47 \mathrm{rpm}$, dan nilai putaran generator maksimum sebesar $94 \mathrm{rpm}$. Nilai tegangan rata rata tanggal 11 Desember 2020 sebesar $0.83 \mathrm{~V}$ dan nilai putaran generator rata rata sebesar $86.6 \mathrm{rpm}$. Nilai tegangan dan RPM yang dihasilkan berbanding lurus. Perubahan nilai ini terjadi karena sifat angin disekitar PLTB fluktuatif. Sekitar pukul 08.00 PLTB menghasilkan tegangan terendah, kemudian kembali meningkat lagi hingga mencapai tegangan 1 volt pada pukul $11.00-12.00$. pada pukul 13.00 tegangan PLTB kembali menurun dan kemudian meningkat secara bertahap hingga pukul 23.00.

B. Hasil Monitoring PLTB 12 Desember 2020

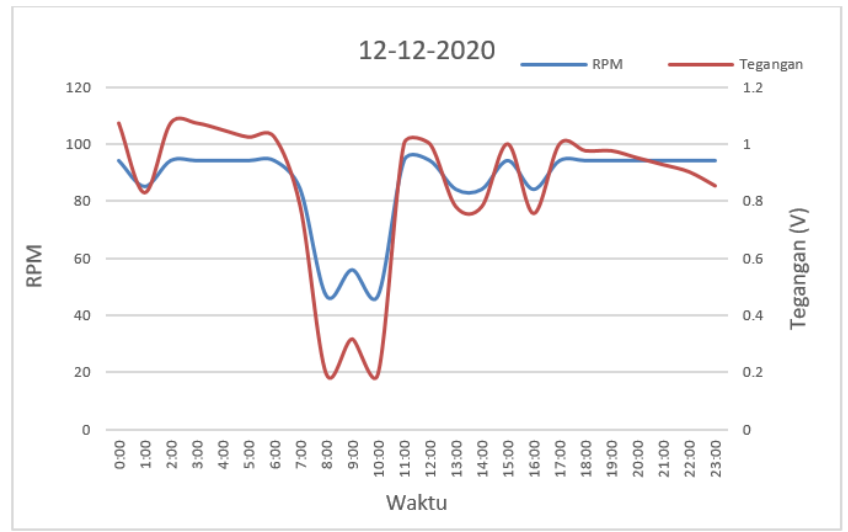

Gambar 7. Hasil Monitoring PLTB 12 Desember 2020

Pada tanggal 12 Desember 2020, nilai tegangan luaran minimum yang termonitor adalah sekitar 0.196 Volt dan nilai tegangan luaran maksimum yang dihasilkan hanya menunjukkan sekitar 1.075 Volt. Nilai putaran generator minimum sebesar $47 \mathrm{rpm}$, dan nilai putaran generator maksimum sebesar $94 \mathrm{rpm}$. Nilai tegangan rata rata tanggal 12 Desember 2020 sebesar $0.85 \mathrm{~V}$ dan nilai putaran generator rata rata sebesar $86.45 \mathrm{rpm}$. Dari pukul 02.00 hingga 06.00 tegangan yang dihasilkan PLTB cukup stabil diatas 1 Volt. Kemudian pada pukul 08.00 dan 10.00 tegangan yang dihasilkan PLTB mencapai titik terendah. Pada pukul 11.00 hingga pukul 17.00 perubahan tegangan PLTB cukup fluktuatif. Dari pukul 08.00 hinggal 23.00 tegangan PLTB menurun secara bertahap.

\section{Hasil Monitoring PLTB 13 Desember 2020}

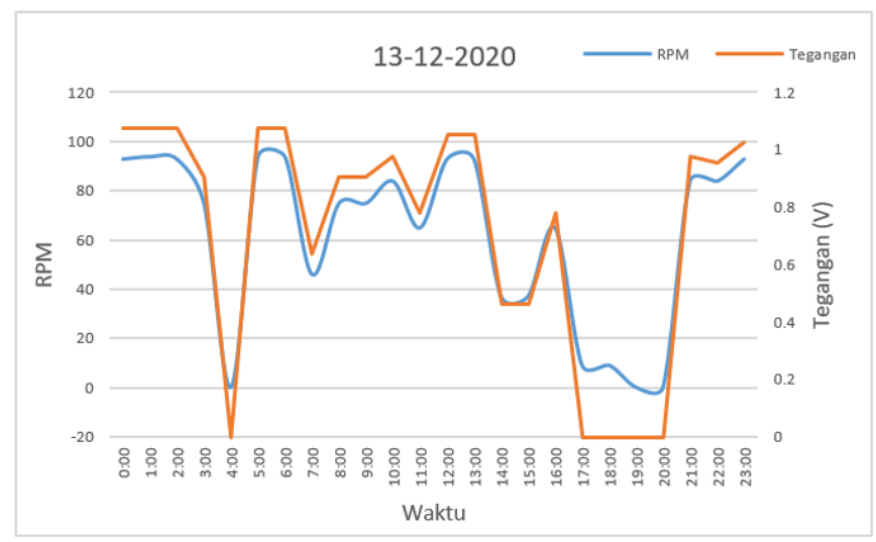

Gambar 8. Hasil Monitoring PLTB 13 Desember 2020

Pada tanggal 13 Desember 2020, nilai tegangan luaran minimum yang termonitor adalah sekitar 0.464 Volt dan nilai tegangan luaran maksimum yang dihasilkan hanya menunjukkan sekitar 1.075 Volt. Nilai putaran generator minimum yang termonitor sebesar $9 \mathrm{rpm}$, dan nilai putaran generator maksimum sebesar $94 \mathrm{rpm}$. Nilai tegangan rata rata tanggal 13 Desember 2020 sebesar $0.718 \mathrm{~V}$ dan nilai putaran generator rata rata sebesar $62.16 \mathrm{rpm}$. Pada pukul 04.00 tegangan pada grafik diatas bernilai 0 , dan nilai putaran generator adalah 0. Pada pukul 17.00 hingga 20.00 sensor kecepatan putaran masih membaca nilai putaran generator, tetapi sensor tegangan tidak membaca tegangan yang dihasilkan generator, hal ini terjadi karena tegangan yang dihasilkan generator sangat kecil dan sensitivitas sensor tegangan tidak dapat membaca nilai tegangan yang dihasilkan.

D. Hasil Monitoring PLTB 14 Desember 2020

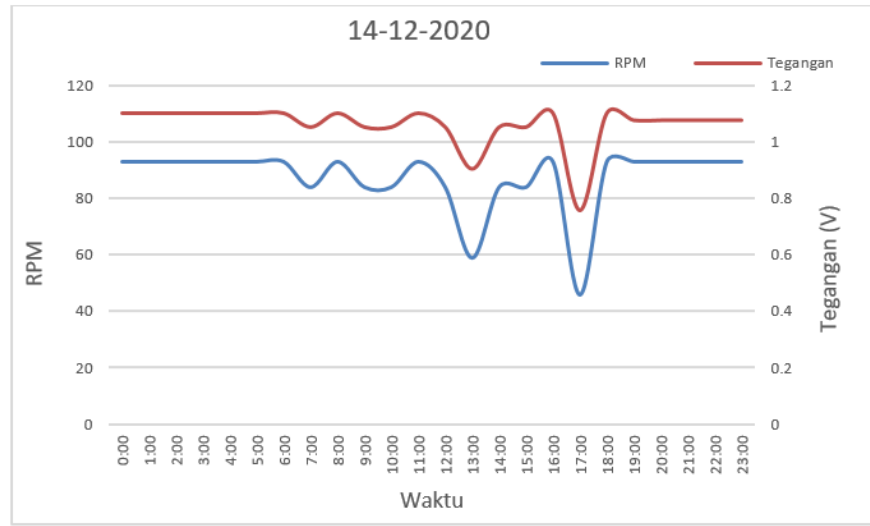

Gambar 9. Hasil Monitoring PLTB 14 Desember 2020 
Pada tanggal 14 Desember 2020, nilai tegangan luaran minimum yang termonitor adalah sekitar 0.758 Volt dan nilai tegangan luaran maksimum yang dihasilkan hanya menunjukkan sekitar 1.1 Volt. Nilai putaran generator minimum yang termonitor sebesar $46 \mathrm{rpm}$, dan nilai putaran generator maksimum sebesar $93 \mathrm{rpm}$. Nilai tegangan rata rata tanggal 14 Desember 2020 sebesar $1.04 \mathrm{~V}$ dan nilai putaran generator rata rata sebesar $85.4 \mathrm{rpm}$. Nilai tegangan yang dihasilkan cukup stabil pada pukul 00.00 hingga 06.00, kemudian tegangan yang dihasilkan cukup fluktuatif dari pukul 06.00 hinggal pukul 11.00. Pada pukul 17.00 tegangan yang dihasilkan mencapai titik terendah, kemudian tegangan terus naik hingga pukul 19.00. Tegangan kembali stabil dari pukul 19.00 hingga 23.00 .

\section{E. Hasil Monitoring PLTB 15 Desember 2020}

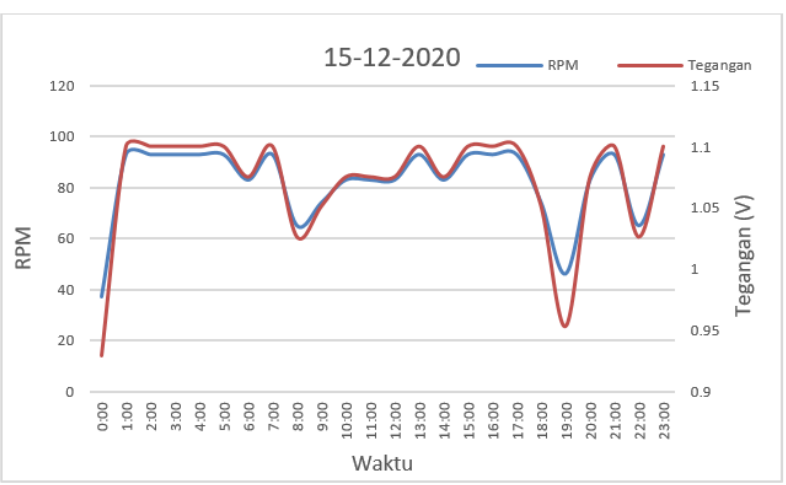

Gambar 10. Hasil Monitoring PLTB 15 Desember 2020

Pada tanggal 15 Desember 2020, nilai tegangan luaran minimum yang termonitor adalah sekitar 0.929 Volt dan nilai tegangan luaran maksimum yang dihasilkan hanya menunjukkan sekitar 1.1 Volt. Nilai putaran generator minimum yang termonitor sebesar $37 \mathrm{rpm}$, dan nilai putaran generator maksimum sebesar $93 \mathrm{rpm}$. Nilai tegangan rata rata tanggal 15 Desember 2020 sebesar $1.07 \mathrm{~V}$ dan nilai putaran generator rata rata sebesar $82.3 \mathrm{rpm}$. Pada pukul 01.00 hinggal 05.00 tegangan yang dihasilkan generator cukup stabil. Kemudian tegangan cukup fluktuatif dari pukul 06.00 hingga pukul 17.00. Tegangan mencapai titik terendah pada pukul 19.00. Dari pukul 19.00 hingga 23.00 perubahan tegangan yang dihasilkan fluktuatif.

\section{F. Hasil Monitoring PLTB 16 Desember 2020}

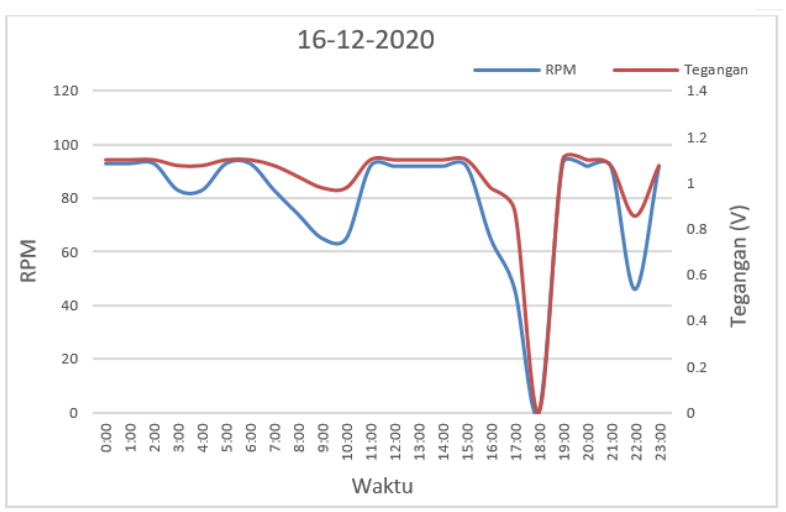

Gambar 11. Hasil Monitoring PLTB 16 Desember 2020
Pada tanggal 16 Desember 2020, nilai tegangan luaran minimum yang termonitor adalah sekitar 0.587 Volt dan nilai tegangan luaran maksimum yang dihasilkan hanya menunjukkan sekitar 1.1 Volt. Nilai putaran generator minimum yang termonitor sebesar $18 \mathrm{rpm}$, dan nilai putaran generator maksimum sebesar $92 \mathrm{rpm}$. Nilai tegangan rata rata tanggal 16 Desember 2020 sebesar $0.975 \mathrm{~V}$ dan nilai putaran generator rata rata sebesar $75.54 \mathrm{rpm}$. Dari pukul 00.00 hingga 16.00 tegangan yang dihasilkan cukup stabil, dimana sedikit terdapat perubahan tegangan yang dihasilkan. Kemudian tegangan yang dihasilkan turun sangat drastis hingga mencapai 0 volt pada pukul 18.00 dan turbin juga tidak berputar karena kecepatan yang terbaca adalah $0 \mathrm{rpm}$. Kemudian pada pukul 19.00 hingga 23.00 turbin angin kembali berputar dan menghasilkan tegangan yang cukup stabil.

G. Hasil Monitoring PLTB 17 Desember 2020

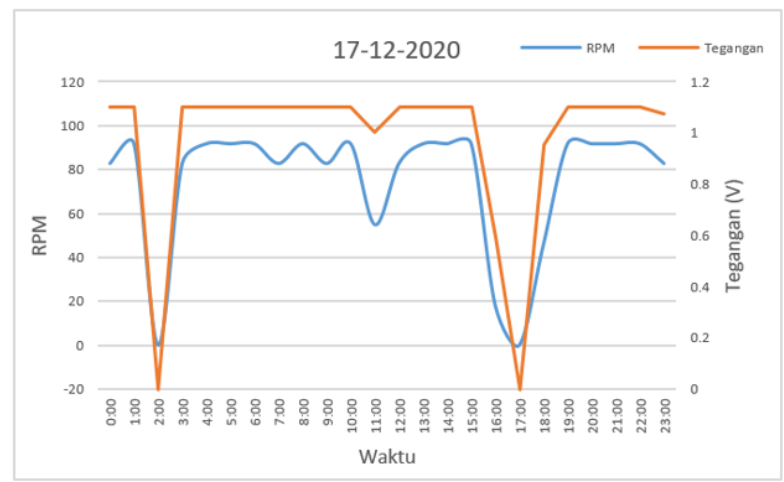

Gambar 12. Hasil Monitoring PLTB 17 Desember 2020

Pada tanggal 17 Desember 2020, nilai tegangan luaran minimum yang termonitor adalah sekitar 0.587 Volt dan nilai tegangan luaran maksimum yang dihasilkan hanya menunjukkan sekitar 1.1 Volt. Nilai putaran generator minimum yang termonitor sebesar $46 \mathrm{rpm}$, dan nilai putaran generator maksimum sebesar $93 \mathrm{rpm}$. Nilai tegangan rata rata tanggal 17 Desember 2020 sebesar $1.01 \mathrm{~V}$ dan nilai putaran generator rata rata sebesar $79.3 \mathrm{rpm}$. Tegangan yang dihasilkan oleh PLTB stabil pada pukul 03.00 hingga 15.00. Kemudian PLTB tidak berputar dan tidak menghasilkan tegangan pada pukul 02.00 dan pukul 17.00.

\section{H. Potensi Daya}

Potensi daya listrik dari PLTB tidak dapat dilakukan perhitungan, karena luaran dari PLTB tidak dihubungkan terhadap beban, sehingga arus tidak dapat dihasilkan. Potensi daya yang dapat dihasilkan oleh PLTB adalah potensi daya angin. Daya angin adalah daya yang dapat dihasilkan dari sudu angin akibat adanya hembusan angin persatuan waktu. Daya angin yang dapat di ekstrasi oleh turbin dapat dirumuskan sebagai berikut [8].

$$
P=\frac{1}{2} \rho \cdot A \cdot v^{3}
$$

Dimana:

$\rho$ : Densitas udara $\left(1.24 \mathrm{~kg} / \mathrm{m}^{3}\right)$

A : Luas sapuan $\left(\mathrm{m}^{2}\right)$

$\mathrm{V}:$ Kecepatan angin $\left(\mathrm{m} / \mathrm{s}^{2}\right)$ 
Nilai kecepatan angin tertinggi dari hasil monitoring pada grafik kecepatan angin yaitu $6.03 \mathrm{~m} / \mathrm{s}$. Turbin angin memiliki spesifikasi diameter sebesar 1.28 meter dan tinggi angin $50 \mathrm{~cm}$. Pada tanggal 11 - 17 Desember 2020 suhu di sekitar PLTB sebesar $21.17^{\circ} \mathrm{C}$, kelembaban sebesar $82.9 \%$, tekanan udara $100745 \mathrm{~Pa}$ didapatkan nilai densitas udara sebesar $1.15 \mathrm{~kg} / \mathrm{m}^{3}$. Luas sapuan turbin dapat dilihat dari gambar berikut [9].
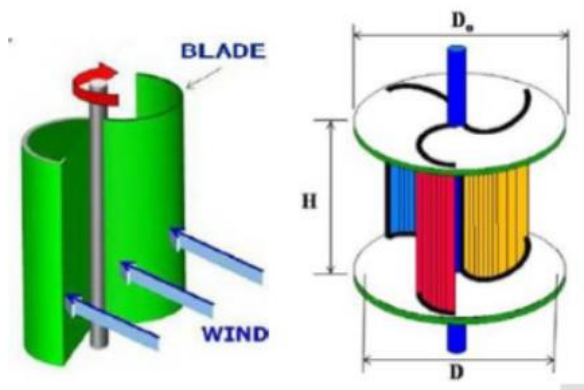

Gambar 13. Luas Sapuan Turbin [9]

Untuk mencari luas sapuan turbin angin dapat dirumuskan sebagai berikut [9].

$$
A=D \cdot H
$$

Luas sapuan turbin dengan melakukan perhitungan menggunakan persamaan (2) sebagai berikut:

$A=D \cdot H$

$A=1.28 \mathrm{~m} \cdot 0.5 \mathrm{~m}$

$A=0.64 m^{2}$

Daya angin maksimum yang dapat dihasilkan oleh turbin dengan perhitungan menggunakan persamaan (1) sebagai berikut:

$P=\frac{1}{2} \rho \cdot A \cdot v^{3}$

$P=\frac{1}{2} \times 1.15 \times 0.64 \times 6.03^{3}$

$P=80.68 \mathrm{Watt}$

Nilai daya angin maksimum yang dapat dihasilkan oleh PLTB jenis savonius 6 sudu adalah 80.68 watt. Daya minimum yang dapat dihasilkan oleh turbin dengan perhitungan menggunakan persamaan Error! Reference source not found. sebagai berikut:

$P=\frac{1}{2} \rho \cdot A \cdot v^{3}$

$P=\frac{1}{2} \times 1.15 \times 0.64 \times 1.01^{3}$

$P=0.38 \mathrm{Watt}$

Nilai daya angin minimum yang dapat dihasilkan oleh PLTB jenis savonius 6 sudu adalah 0.38 watt. Berikut grafik potensi daya angin yang dapat di ekstraksi oleh turbin angin periode 1117 Desember 2020.

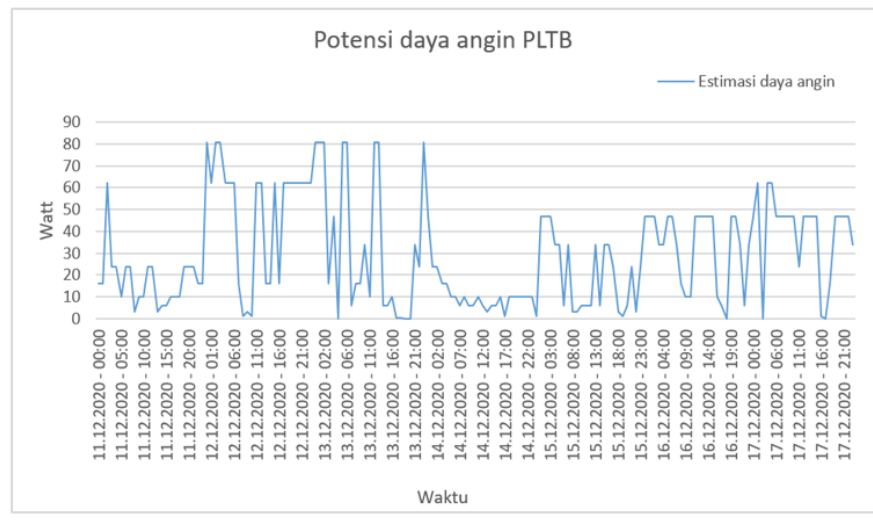

Gambar 14. Grafik potensi daya angin PLTB periode 11-17 Desember 2020

\section{Karakteristik Generator PLTB}

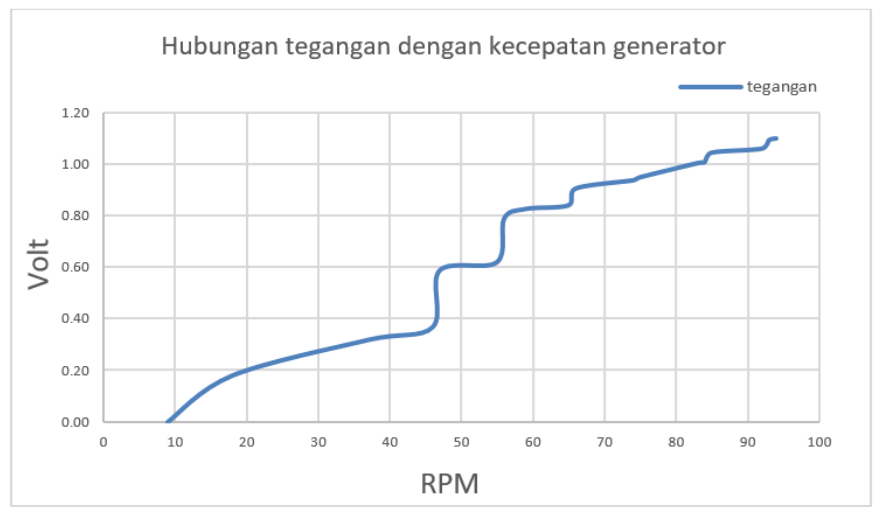

Gambar 15. Grafik hubungan tegangan dan kecepatan generator

Berdasarkan grafik hubungan pada Gambar 15, tegangan berubah hampir linier seiring dengan meningkatnya kecepatan putaran generator. Kecepatan generator minimum yang termonitor yaitu $9 \mathrm{rpm}$. Saat kecepatan generator bernilai $9 \mathrm{rpm}$ tidak ada tegangan yang dihasilkan oleh generator. Generator mulai menghasilkan tegangan minimum sebesar $0.18 \mathrm{~V}$ saat kecepatan putaran bernilai $18 \mathrm{rpm}$. Kecepatan generator maksimum pada PLTB di Politeknik Negeri Batam yaitu 94 rpm dengan tegangan yang dihasilkan sebesar 1.1V.

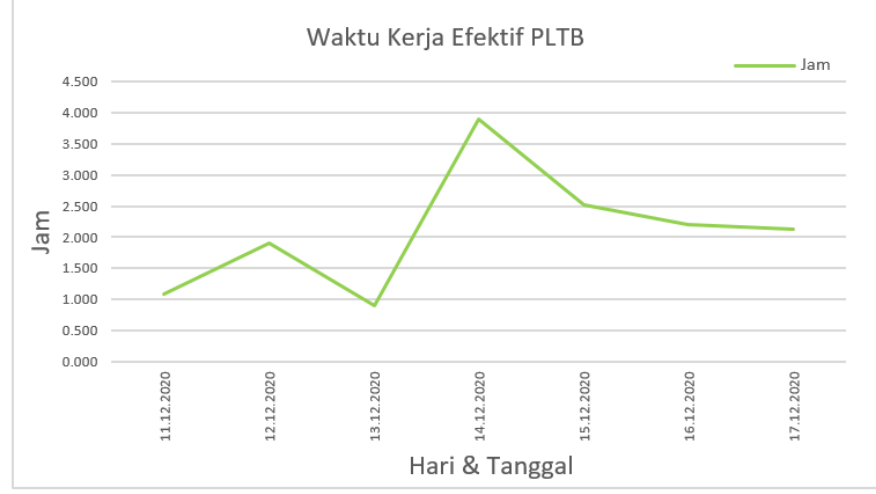

Gambar 16. Grafik Waktu Kerja Efektif PLTB dalam Menghasilkan Tegangan

Dalam satu hari tidak setiap waktu PLTB berputar dan menghasilkan tegangan luaran. PLTB akan berputar dan menghasilkan tegangan luaran akibat adanya hembusan angin. Pada tanggal 13 Desember 2020 adalah waktu kerja efektif minimum PLTB, dimana hanya bekerja selama 0.89 jam atau 
sekitar 53 menit dalam satu hari. Pada tanggal 15 Desember 2020 adalah waktu kerja efektif maksimum PLTB, dimana PLTB bekerja efektif selama 2.5 jam atau sekitar 150 menit dalam sehari. Waktu kerja efektif PLTB dipengaruhi oleh kecepatan angin di lingkungan sekitar PLTB, dimana saat tidak ada angin yang berhembus maka PLTB tidak dapat berputar dan tidak dapat menghasilkan energi listrik. Selama periode 11-17 Desember 2020 jumlah waktu kerja efektif PLTB untuk menghasilkan tegangan luaran di Politeknik Negeri Batam sebesar 14.6 jam atau sekitar 878.2 menit dengan rata-rata waktu kerja efektif per hari sebesar 2.1 jam atau sekitar 125.5 menit.

\section{KESIMPULAN}

Pembuatan sistem monitoring luaran pico generator menggunakan arduino secara real-time dan aplikasi penampil data monitoring sudah terealisasi. Hasil pengujian tanggal 1117 Desember 2020 PLTB menunjukkan sistem PLTB di Politeknik Negeri Batam dapat bekerja efektif selama 14.6 jam selama satu minggu atau 2.1 jam per hari. Berdasarkan data hasil pengujian pada periode tersebut potensi maksimum daya angin yang dapat di ekstraksi oleh turbin angin di lokasi PLTB Politeknik Negeri Batam sebesar 80.68 watt dan potensi daya angin minimum sebesar 0.38 watt. Tegangan maksimum yang dapat dihasilkan oleh PLTB di Politeknik Negeri Batam sebesar 1.1 volt dan tegangan luaran harian memiliki rentang 0.147 volt hingga 1.1 volt. Nilai tegangan luaran berbanding lurus dengan kecepatan putaran generator PLTB. Kecepatan putaran generator PLTB dipengaruhi oleh kecepatan angin di lingkungan Politeknik Negeri Batam.

\section{REFERENSI}

[1] A. K. Azad, M. G. Rasul, R. Islam, and I. R. Shishir, "Analysis of Wind Energy Prospect for Power Generation by Three Weibull Distribution Methods," in Energy Procedia, 2015, vol. 75, pp. 722-727, doi: 10.1016/j.egypro.2015.07.499.

[2] Y. D. Herlambang, B. Prasetiyo, S. Supriyo, W. Wahyono, and T. H. Mulud, "Model Turbin Angin Airfoil Naca 4418 Terhadap Variasi Bukaan Sudut Sudu Pada Kecepatan Angin Berbeda," J. Integr., vol. 11, no. 2, pp. 97-102, 2019, doi: 10.30871/ji.v11i2.1659.

[3] I. Z. Putra, F. Atabiq, and A. F. Juwito, "Pemanfaatan Motor Induksi Satu Fase Sebagai Pico Generator untuk Sumber Energi Alternatif Terbarukan Pembangkit Listrik Tenaga Bayu di Politeknik Negeri Batam," J. Appl. Electr. Eng., vol. 3, no. 2, pp. 36-38, 2019, doi: 10.30871/jaee.v3i2.1768.

[4] M. R. Fachri and H. Hendrayana, "Analisa Potensi Energi Angin dengan Distribusi Weibull Untuk Pembangkit Listrik Tenaga Bayu (PLTB) Banda Aceh," CIRCUIT J. Ilm. Pendidik. Tek. Elektro, vol. 1, no. 1, pp. 1-8, 2017, doi: 10.22373/crc.v1i1.1377.

[5] L. Q. Sang, T. Maeda, and Y. Kamada, "Study effect of extreme wind direction change on 3-bladed horizontal axis wind turbine," Int. J. Renew. Energy Dev., vol. 8, no. 3, pp. 261-266, 2019, doi: 10.14710/ijred.8.3.261-266.

[6] W. B. Pramono, W. Warindi, and A. Hidayat, "Perancangan Mini Generator Turbin Angin 200 W untuk Energi Angin Kecepatan Rendah," Seminar Nasional Teknologi dan Informatika 2015. Indonesia, 2015.

[7] B. Suryadi and Sugiyanto, "PENGUJIAN GENERATOR MULTI POLE MODIFIKASI PADA VERTICAL AXIS WIND TURBINE (VAWT) TIPE SAVONIUS," Univ. Gadjah Mada, 2016.

[8] S. Mathew, Wind energy: Fundamentals, resource analysis and economics. 2007.

[9] M. R. M. Khandagale and M. B. G. Marlapalle, "Design \& Analysis of Savonius VAWT for 50W Rated Power output," 2017. 